\title{
ROLE OF MILLIPEDES (Orthoporous ornatus) IN ENRICHING THE SOIL pH, MACRONUTRIENTS (N, P, K) AND ORGANIC CARBON
}

\author{
Dr.S.Kalaichelvi ${ }^{1 *}$, V. Dhivya Bharathi ${ }^{2}$, T. Divya ${ }^{3}$, M. Gayathri ${ }^{4}$, K. Idhaya ${ }^{5}$, \\ R. Indhirani ${ }^{6}$ \\ ${ }^{1}$ UG - ZOOLOGY, Associate Professor, Sri G.V.G Visalakshi College for Women (Autonomous) \\ Udamalpet, Tirupur District,Tamil Nadu. \\ ${ }^{2-6}$ III B.Sc ZOOLOGY Student, Sri G.V.G Visalakshi College for Women (Autonomous) \\ Udamalpet, Tirupur District,Tamil Nadu.
}

\begin{abstract}
Aim of the research is to observe the millipede (Orthoporous ornatus) biology and its behavior. We have analyzed the soil samples to find out the soil nutrients level in control and experimental soil with $\mathrm{pH}$, Macronutrients $(\mathrm{N}, \mathrm{P}, \mathrm{K})$ and Organic Carbon. The current research was done in our college campus. Soil biodiversity reflects the mix of living organisms in the soil. These organisms interact with one another and with plants and small animals forming a web of biological activity. Soil is by far the most biologically diverse part of Earth. Most millipedes are slow-moving detritivores, eating decaying leaves and other dead plant matter. Some eat fungi or suck plant fluids, minority of them are predatory. Most millipedes defend themselves with a variety of chemicals secreted from pores along the body.There is revived focus on the once-neglected millipede for its use in composting and improvement of soil quality. Some of the millipedes are more efficient than the earthworms in this. About 270 species have been identified in India of which, at least 93 are from south India. The millipede shows favorable result in managing nutrients in experimental soil than control soil.
\end{abstract}

Key Words: Millipede, Orthoporous ornatus, pH, Macronutrients, Organic Carbon, Experimental soil and Control soil.

\section{INTRODUCTION}

Millipedes are discovered 425 million years ago fossil from the Scottish island of Kerrera is the world's oldest bug. The terms millipede was coined by American scientists Hoffman Richard L. in 1990. Millipede has another name thousand leggers or diplopods. About 270 species have been identified in India of which, at least 93 are from south India. Millipedes are soil specialists living on the ground, in shallow sub-terranean habitat, among the leaflitters or in the soil. They are adapted to live in humid conditions under moderate temperatures, so are predominantly abundant in the tropics and sub-tropical regions of the globe. Forest floors with abundance of leaf litter are fairly wellbuffered against temperature and moisture fluctuations thus providing the millipedes with a favourable environment.(1)

Aim of the research is to observe the millipede (Orthroporous ornatus) biology, behavior and their role in soil. We have analyzed the soil samples to find out the soil nutrients level in control and experimental soil with $\mathrm{pH}$, Macronutrients (N, P, K) and Organic Carbon. The current research was done in our college campus. The research motive is to prove the role of Orthroporous ornatus on environment.

\section{EXPERIMENTAL METHODS}

The nocturnal millipede Orthroporous ornatus are present in the college campus. The nymph and adult were collected and observed under the laboratory condition. The nymphs were kept in the tray with soil. Dry leaves and plant materials fed to the millipedes. The nymphs were growing up to the adult stage. With constant intervals the weight and length of the millipedes were measured. In experimental soil the millipedes were reared. The control soil is available in the college campus. The control and experimental soil samples were undergone for analysis. The soil $\mathrm{pH}$, macronutrients $(\mathrm{N}, \mathrm{P}, \mathrm{K})$ and organic carbon were analyzed. 


\section{International Advanced Research Journal in Science, Engineering and Technology}

Vol. 8, Issue 9, September 2021

\section{DOI: 10.17148/IARJSET.2021.8970}

Duration of the Research: The duration of the research work started from the month of December 2019 - March 2020. Behavior: Orthoporus ornatus likes to stay in the deep damp soil of an ecosystem. The organism living under the soil. The soil is full of honey-comb like structures and tunnels (21). This is a slow-moving millipede that enjoys feeding on decaying materials. (12) It is mostly nocturnal; however, it can be spotted after rainy days in the early mornings. It spends most of its time in self-dug burrows (4). It will emerge from the soil only when the soil is moist. Once the soil is dried up from the desert sun it will go back into the deep soil (13). Through studies, it was said that movement was at its peak during the early mornings with some nocturnal activity as well. It was found under rocks and sometimes on the aerial portions of shrubs. When it was found on shrubs the air temperature was 35.5 degree Celsius (23)

Ecology and Feeding Habits: Main food source of millipedes are soil bacteria, which thrive in the damp soil that it lives around. It will feed on dead plant material and tissues of dead shrubs. It also eats tiny pieces of sand, rock and other invertebrate animals (arthropods). It cannot eat in the absence of moist soil (16) The millipede has certain defenses against its predators, but some vertebrates find that preying on this organism. There are about thirteen species that have been observed to feed on millipedes (7).

Interactions with Humans: The millipede is a very simple creature and harmless. It will curl up into a ball, or coil, when it is disturbed. It releases a noxious substance out from the side of its body, or through glands on top of its legs the skin of a man and irritate the eyes. It is toxic to anything that might eat it. (12).

\section{RESULTS}

Life Cycle: The life cycle of a millipede from egg to mature adult can take time and patience. Ensure the habitat is escape proof since millipedes can easily crawl up and out of most open tanks. Habitat needs to maintain some humidity by add a bit of water to the substrate to keep it moist and to increase the humidity. (1)

Eggs: A few weeks after mating occurs, the female millipede will dig into the soil of the tank and will lay eggs. The eggs they laid blend into the soil the female usually protect the area where buried the clutch of eggs that develop young millipedes Females can lay up to 100 eggs at a time and increase the amount of soil to make sure the nymphs to moult. On an average, millipede eggs take three months to hatch.

Nymph: The eggs hatch out as nymphs not look much like millipedes. These young ones have a few body segments and more than four pairs of legs. In comparison, adult millipedes have from 30 to 350 pairs of legs. The millipede will dig itself into in the soil when it is ready to moult and will emerge with more body segments each time and reach their full size in two to five years.

Adult: Adult millipedes need a healthy environment with 4 inches of soil so the millipedes have plenty of room to move around and to lay more eggs. Branches, wood, moss and other items add to the growing tray to create a more pleasant environment for the millipedes They also need calcium and fresh water (1).

$E G G$

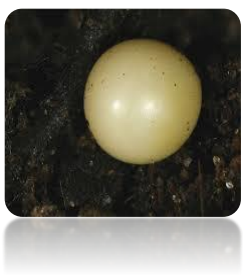

NYMPH

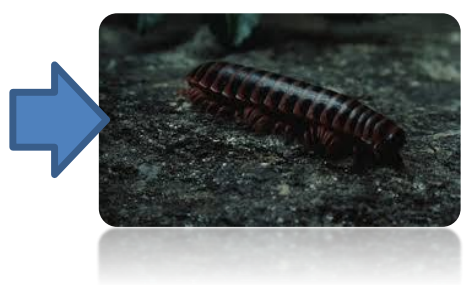

ADULT

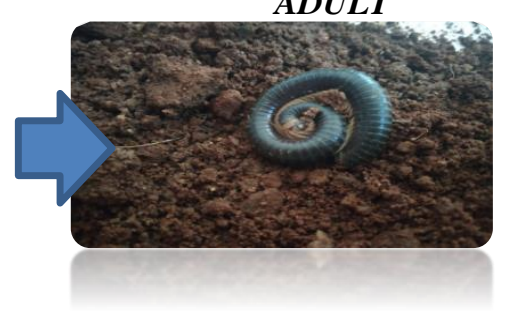

The weight and length of the millipede were measured day by day. It is represented with the tabulation and graph.

Tabulation Representation:

\begin{tabular}{|l|l|l|l|l|l|}
\hline Day & Date & Initial Length & Final Length & Initial Weight & Final Weight \\
\hline 1 & $13 / 12 / 2019$ & $10.8 \mathrm{~cm}$ & $0 \mathrm{~cm}$ & $3.65 \mathrm{gm}$ & $0 \mathrm{gm}$ \\
\hline 2 & $20 / 12 / 2019$ & $11.0 \mathrm{~cm}$ & $0.2 \mathrm{~cm}$ & $3.82 \mathrm{gm}$ & $0.3 \mathrm{gm}$ \\
\hline 3 & $27 / 12 / 2019$ & $11.4 \mathrm{~cm}$ & $0.4 \mathrm{~cm}$ & $4.12 \mathrm{gm}$ & $0.24 \mathrm{gm}$ \\
\hline 4 & $03 / 01 / 2020$ & $11.7 \mathrm{~cm}$ & $0.3 \mathrm{~cm}$ & $4.45 \mathrm{gm}$ & $0.33 \mathrm{gm}$ \\
\hline 5 & $10 / 01 / 2020$ & $12.2 \mathrm{~cm}$ & $0.5 \mathrm{~cm}$ & $4.59 \mathrm{gm}$ & $0.14 \mathrm{gm}$ \\
\hline 6 & $17 / 01 / 2020$ & $12.9 \mathrm{~cm}$ & $0.7 \mathrm{~cm}$ & $4.79 \mathrm{gm}$ & $0.20 \mathrm{gm}$ \\
\hline 7. & $31 / 01 / 2020$ & $13.7 \mathrm{~cm}$ & $0.3 \mathrm{~cm}$ & $5.13 \mathrm{gm}$ & $0.16 \mathrm{gm}$ \\
\hline
\end{tabular}

Graphical Representation: 


\section{International Advanced Research Journal in Science, Engineering and Technology}

Vol. 8, Issue 9, September 2021

DOI: 10.17148/IARJSET.2021.8970

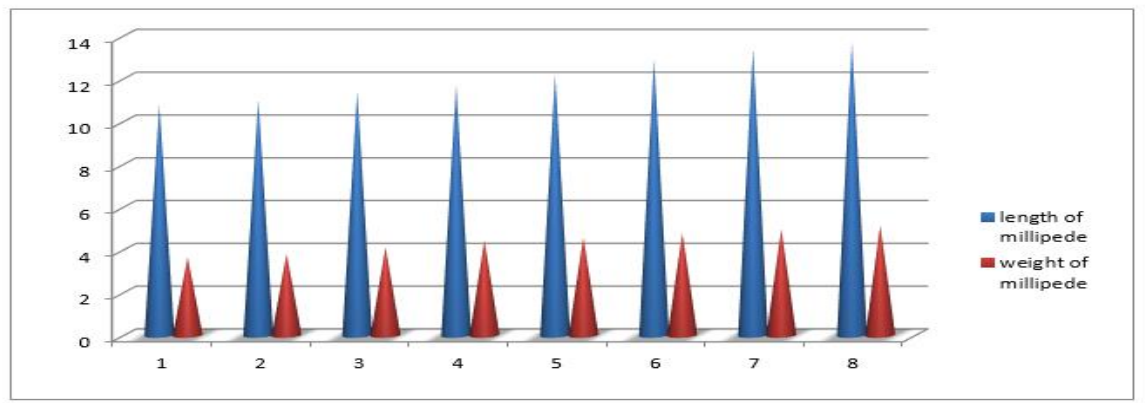

Soil Test: The soil samples were tested in TAMILNADU AGRICULTURAL UNIVERSITY, COIMBATORE to know the in $\mathrm{pH}$ and Macronutrients $(\mathrm{N}, \mathrm{P}, \mathrm{K})$ and Organic Carbon in Control soil and Experimental soil. The soil test procedures and results are given below.

\begin{tabular}{|l|l|l|}
\hline Name of the Analysis & Control Soil & Experimental Soil \\
\hline pH & 7.07 & 6.45 \\
\hline Nitrogen ( Kg hg ${ }^{1}$ ) & 258 & 314 \\
\hline Phosphorous ( Kg hg ${ }^{1)}$ & 41.8 & 33.8 \\
\hline Potassium ( Kg hg ${ }^{1)}$ & 650 & 409 \\
\hline Organic carbon $\left(\mathrm{g} \mathrm{Kg}^{1}\right.$ ) & 5.52 & 4.68 \\
\hline
\end{tabular}

pH

Soil $\mathrm{pH}$ refers to the acidity or alkalinity of the soil. It is a measure of the concentration of free hydrogen ions $(\mathrm{H}+)$ that are in the soil. Soil $\mathrm{pH}$ can be measured in water $(\mathrm{pH})$ or a weak calcium chloride solution $(\mathrm{pH})$. The $\mathrm{pH}$ range is from 0 -14, with value of 6.45 being acidic

Procedure: Half a teaspoon of soil kept on the plate. Add enough dye to saturate onto the soil mix and allow the colour to develop. Compare the sample colour with the $\mathrm{pH}$ colour chart (2). Record results.

Result: $\mathrm{pH}$ of control soil is alkaline $\mathrm{pH}$ (7.07) and experimental soil is alkaline $\mathrm{pH}(6.45)$.

\section{NITROGEN}

Procedure: Test tube filled with Nitrogen Extracting Solution. Use the $0.5 \mathrm{~g}$ spoon to add two measures of soil sample and gently shake for one minute and allow soil to settle. Use a clean pipette to transfer the clear liquid to a second test tube. The bulb released slowly to draw clear liquid into the pipette. Second tube filled with liquid. Use the 0.25 (smaller) spoons to add two measures of nitrogen indicator powder to the soil extract in the second tube. Cap and gently shake to mix. Wait 5 minutes for the pink colour to develop above the powder. Match the test colour with the nitrogen colour chart. Record as nitrogen (N) on the data sheet (15).

Result: The volume of nitrogen in control soil is $258 \mathrm{Kgh}^{1}$ and experimental soil is $314 \mathrm{Kgh}^{1}$.

\section{PHOSPHOROUS}

Procedure: Use the $0.5 \mathrm{~g}$ spoon to add three measures of soil sample. Cap and gently shake for one minute. Remove cap and allow to stand and soil to settle until liquid above the soil is clear. Then transfer the clear liquid to a second clean test tube. To avoid agitation of soil squeeze the bulb of the pipette before inserting tip into liquid. Release bulb slowly to draw clear liquid into the dropper. Six drops of the Phosphorus Indicator Reagent added to soil extract in the second tube. Cap and shake to mix the contents. One phosphorus test tablet should be added. Shake vigorously until the tablet is dissolved. A blue colour will develop. Match the test colour with the phosphorus colour chart. Record this phosphorus level on data sheet (22)

Result:The volume of phosphorus in control soil is 41.8 and in experimental soil is 33.8 .

\section{POTASSIUM}

Procedure: $0.5 \mathrm{~g}$ spoon to add four measures of soil sample to test tube. cap and shake vigorously for one minute and allow soil to settle. Use a clean pipette to transfer liquid to test tube. One potassium indicator tablet to be added to the soil extract in the second tube. cap and shake to dissolve the tablet and purplish colour will appear. Potassium test solution added two drops at a time. Keep a running count of the drops used. Swirl the test tube after each addition to mix the contents. Stop adding drops when the colour changes from purplish to blue. Record the total number of drops added. Use the potassium end point colour chart as a guide in reading this colour change (8)

Result: The amount of potassium in control soil is 650 and in experimental soil is 409 . 


\section{ORGANIC CARBON}

Estimates of total organic carbon are used to assess the amount of organic matter in soils. The method measures the amount of carbon in plant and animal remains, including soil humus but not charcoal or coal. Levels are commonly highest in surface soils but wide variations from almost zero to above $15 \% \mathrm{C}$ are possible.(18)

Procedure: Determine the moisture content of the air-dry soil which has been ground to pass a $0.42 \mathrm{~mm}$ sieve. Weigh accurately enough soil to contain between $10 \mathrm{mg}$ and $20 \mathrm{mg}$ of carbon into a dry tarred $250 \mathrm{~mL}$ conical flask (between $0.5 \mathrm{~g}$ and $1 \mathrm{~g}$ for topsoil and $2 \mathrm{~g}$ and $4 \mathrm{~g}$ for subsoil). Accurately add $10 \mathrm{~mL} 1 \mathrm{~N} \mathrm{~K} 2 \mathrm{~N} \mathrm{~K} 2 \mathrm{Cr} 2 \mathrm{O} 7$ and swirl the flask gently to disperse the soil in the solution. Add $20 \mathrm{~mL}$ concentrated $\mathrm{H} 2 \mathrm{SO} 4$, directing the stream into the suspension. Immediately swirl the flask until the soil and the reagent are mixed. Insert a $200{ }^{\circ} \mathrm{C}$ thermometer and heat while swirling the flask and the contents on a hot plate or over a gas burner and gauze until the temperature reaches $135{ }^{\circ} \mathrm{CSet}$ aside to cool slowly on an asbestos sheet in a fume cupboard. Two must be run in the same way to standardize the FeSO4 solution. When cool (20-30 minutes), dilute to $200 \mathrm{~mL}$ with deionized water and proceed with the FeSO4 titration using either the "ferroin" indicator or potentiometrically with an expanding scale $\mathrm{pH} / \mathrm{mV}$ meter or auto titrator (10)

Result: The organic carbon in control soil is 5.52 and experimental soil is 4.68 .

\section{DISCUSSION}

Soil biodiversity reflects the mix of living organisms in the soil. These organisms interact with one another and with plants and small animals forming a web of biological activity. The soil food web includes beetles, springtails, mites, worms, millipedes, spiders, ants, nematodes, fungi, bacteria, and other organisms. These organisms improve the entry and storage of water, resistance to erosion, plant nutrition, and break down of organic matter.(20.)Earthworms, dung beetles, spiders, ants and cicadas make vertical tunnels that open to the soil surface and water can infiltrate.(6) The formation of holes or macropores in the soil, helps water transmission and soil hydrology. Soil animals mix soil layers together and also mix organic matter that they eat with mineral soil layers from the surface and deposit.(7) This helps water retention in soil. Earthworm activity lowers soil bulk density and makes soil more friable. Plant roots can penetrate this soil more easily (5) Millipedes (Diplopoda) are a highly diverse group of soil invertebrates and play vital roles in terrestrial ecosystems. Millipedes contribute to the cycling of carbon and nutrients through their feeding activities and gut processes that help decompose litter. (4).

\section{Roles of soil organisms}

There are three main roles that millipedes and other soil organisms perform in soil.

- Decompose organic residues

- Re-cycle nutrients from organic residues

- Enhance soil structure

pH: Soil pH refers to the acidity or alkalinity of the soil. It is a measure of the concentration of free hydrogen ions (H+) that are in the soil. Here the control soil shows alkaline PH but the experimental soil shows the acidic PH.

Nitrogen: Nitrogen $(\mathrm{N})$ is important for plant growth and development, and of the macronutrients are often the one that is essential. Knowing the content of plant available nitrogen is important to assure that the crop has enough for adequate growth, but excess nitrogen is not running off the field. Here the control soil shows low nitrogen. But the experimental soil shows more volume of nitrogen which is increased by the activity of millipede. The amount of nitrogen contain in experimental soil is higher than control soil. Nitrogen is more in experimental soil and increases the soil fertility with more crop yield.(14)

Phosphorous: Phosphorus plays an important role in plant health and growth; it encourages root development, increases the ratio of grain to straw, and increases resistance to disease, among other thing. Here the control soil is having more phosphorous than experimental soil which shows the phosphorous utilized for the metabolic activity of millipede and play a vital role.

Potassium: Potassium (K) enhances disease resistance in plants by strengthening stalks and stems, contributes to a thicker cuticle which guards against disease and water loss, controls the turgor pressure within plants to prevent wilting, and enhances fruit size, flavor, texture and development. The control soil shows more potassium than experimental soil which is utilized by the millipede for its metabolic activity (3)

Organic Carbon: Estimates of total organic carbon are used to assess the amount of organic matter in soils.(9)The method measures the amount of carbon in plant and animal remains, including soil humus but not charcoal or coal.(10) Soil organisms clear away and degrade organic debris such as dead plants, animal dung and use it as a source of food and nutrients, (11) In the process release nutrients into the soil solution so that living plants may re-use them. (17) Here the control soil has more organic carbon than experimental soil. It shows the organic carbon is utilized for the metabolic activity of millipede (19) 


\title{
International Advanced Research Journal in Science, Engineering and Technology
}

\author{
Vol. 8, Issue 9, September 2021
}

DOI: $10.17148 /$ IARJSET.2021.8970

\section{CONCLUSION:}

Most millipedes are slow-moving detritivores, eating decaying leaves and other dead plant matter. Some eat fungi or suck plant fluids, and a small minority are predatory. There is revived focus on the once-neglected millipede for its use in composting and improvement of soil quality. Some of the millipedes are more efficient than the earthworms. Correspondingly, charismatic species such as tigers, elephants, apes, birds, snakes, turtles, frogs, butterflies and dragonflies are the attention-grabbers of the animal world. But it is in the ecosystem of the soil where it lies a small, private invertebrate that toils to provide ecosystem services far greater than those provided by charismatic animals. The millipede, the veteran of soil ecosystem, is in dire need of attention as it is hurtling towards extinction.

Orthoporus ornatus can be seen as a beneficial and useful part of the soil ecosystem. Because the dead plants and animals take an extra-long time to fully decay. The millipede will eat on these decaying matters and "clean up" their environment. If these small organisms did not exist, the ecosystem would overpopulate with dead plants, dead animals and bacteria. Decomposition and Nutrient Cycling Decomposer invertebrate animals and microbes have quite distinct roles in breaking down organic detritus. Although invertebrates play only a small part in chemically degrading organic detritus, they help the more important microbes in many ways to do their job. During decomposition of organic matter, nutrients are released.The experimental soil is having favorable result in $\mathrm{pH}$ value, increased volume of Nitrogen than control soil which increases the crop yield. Especially we wish to coin a name for Orthroporous ornatus is a "Farmer's Friend".

\section{REFERENCES}

1. Amy S. Jorgensen, life cycle of millipedes October 19, 2017.

2. American Society of Testing and Materials (ASTM). 1995. Annual Book of ASTM Standards, Designation D4972 - 95a: Standard Test Method for $\mathrm{pH}$ of Soils.

3. Association of Official Agricultural Chemists. 1955. Official Methods of Analysis. Eighth Edition, Chapter 3. Benjamin Franklin Station, Washington, D.C. 2.

4. Desert Millipoede (OrthoporusOrnatus)". Arizona Wildlife. 10 Aug. 2008. Accessed 18 Dec. 2014.

5. The Role of Soil Organisms on Soil Stability; (A Review)1Einallah Hesammi, 2Ali Farshidi, 3Farhan Sadatebrahimi and 4Ali BenJavad Talebi 1,2,3,4Department of Agronomy, Shoushtar Branch, Islamic Azad University, Shoushtar, Iran International Journal of Current Life Sciences - Vol.4, Issue, 11, pp. 10328-10334, November, 2014

6. Farshidi, 3Farhan Sadatebrahimi and 4Ali BenJavadTalebi, (November, 2014) The Role of Soil organisms on Soil Stability; (A REVIEW) International Journal of Current Life Sciences - Vol.4, Issue, 11, pp. 10328-10334.

7. Forthman, Michael, and Christiane Weirauch. "Toxic Associations: A Review of the Predatory Behaviors of Millipede Assassin Bugs." Proquest. European Journal of Entomology, 5 Apr. 2012. Web. 18 Dec. 2014).

8. Huang P.M. (2005): Chemistry of potassium in soils. Chapter 4. In: Tabatabai M.A., Sparks D.L. (eds.): Chemical Processes in Soils. Madison, SSSA.

9. Kay, B.D., 1998. Soil structure and organic carbon: a review. In: Lal, R., Kimble, J.M., Follett, R.F., Stewart, B.A. (Eds.), Soil Processes and the Carbon Cycle. CRC Press, Boca Raton, FL, pp. 169- 197.

10. McLeod, S 1973, Studies on wet oxidation procedures for the determination of organic carbon in soils. CSIRO Division of Soils, Notes on Soil Techniques, pp73-79.

11. Martens, D.A., 2000a. Plant residue biochemistry regulates soil carbon cycling and carbon sequestration. Soil Biology and Biochemistry 32 .

12. "Millipedes". National Park Service.U.S. Department of the Interior. 18 Dec. 2014.

13. $\quad$ Prendergast, Katie. "Biodiversity in Arizona."Proquest. Natural History, 1 June 1998. Web. 18 Dec. 2014.

14. Rayment, GE \& Higginson, FR 1992, Australian Laboratory Handbook of Soil and Water Chemical Methods, Melbourne, Inkata Press. (Australian Soil and Land Survey Handbooks, vol

15. Rees R M; Baddeley J A; Bingham I J; Watson C A (2006). Nitrogen uptake by spring barley grown with red and white clover. Org anic Farming and European Rural Development, 300-301.

16. R. C. Wooten, Jr., C. S. Crawford \& W. A. Riddle (1975). "Behavioural thermoregulation of Orthoporus ornatus (Diplopoda: Spirostreptidae) in three desert habitats". Zoological Journal of the Linnean Society).

17. Six, J., Elliott, E.T., Paustian, K., 2000b. Soil structure and soil organic matter. II. A normalized stability index and the effect of mineralogy. Soil Sci. Soc. Am. J. 64, 1042-1049.

18. Tiessen H, Cuevas E, Chacon P. 1994. The role of soil organic matter in sustaining soil fertility. Nature. 371:783-785.

19. Tisdall, J.M., Oades, J.M., 1982. Organic matter and water-stable aggregates in soils. J. Soil Sci. $62,141-163$.

20. U. Irmler, "Changes in the fauna and its contribution to mass loss and N release during leaf litter decomposition in two deciduous forests," Pedobiologia, vol. 44, no. 2, pp. 105-118, 2000

21. Vilani, M. G., L. L. Allee, A. Diaz, and P. S. Robbins. "Adaptive Strategies of Edahic Arthropods."Proquest. Annual Review of Entomology, 1 Jan. 1999. Web. 18 Dec. 2014.

22. W. M. H., and E. G. Williams. 1955. Observations on the determination of total organic phosphorus in soil. Journal of Soil Science 6:254-267.

23. Wooten, Jr., R. C., and C. S. Crawford. "Food Ingestion Rates and Assimilation in the Desert Millipede." Department of Biology, University of New Mexico, 19 Mar. 1975. Web. 18 Dec 2014 